\title{
OVERVIEW OF UZBEK AND AZERBAIJANI SCIENTIFIC-RESEARCH COLLABORATION DURING THE YEARS OF INDEPENDENT DEVELOPMENT
}

\author{
Azer Nadir ogli Adygezalov \\ Andizhan State University, Andizhan, Uzbekistan
}

\begin{abstract}
Introduction. The author provides data about coming into being of Uzbek and Azerbaijani scientific collaboration during the years of independent development of the two countries. The article deals with solid contractual basis in the scientific sphere, including the agreements between the Ministries of Public Education, Academies of Sciences, higher education institutions of the two countries, and with the collaboration in the field of the attestation of highly-qualified scientific and scientific-pedagogical personnel. Methods and materials. The given article also contains information about the direct co-operation of the two states in the sphere of natural, exact sciences and humanities, furthering close and fruitful interrelation of the two countries' scientific circles, covering all the given sphere's branches of partnership relations. Analysis. The article analyzes the process of multifaceted scientific cooperation between Uzbekistan and Azerbaijan, which occurs through the establishment of close contacts between scientists and research centers of the two countries, the implementation of joint research on pressing issues, mutual internships and scientific business trips, as well as the participation in international scientific conferences and symposiums. Close mutual contacts are also carried out in the form of the exchange of scientific personnel and work. Results. The multifaceted Uzbek-Azerbaijani scientific cooperation considered in the article is represented by the following factors: bilateral agreements and arrangements in the scientific field; direct development in the field of natural, exact sciences and humanities; implementation of mutual internships and scientific missions; exchange of scientific personnel and labor.

Key words: Uzbek and Azerbaijani interrelation, scientific collaboration, Ministry of public education, Academy of Sciences, higher education institution.

Citation. Adygezalov A.N. ogli. Overview of Uzbek and Azerbaijani Scientific-Research Collaboration During the Years of Independent Development. Vestnik Volgogradskogo gosudarstvennogo universiteta. Seriya 4. Istoriya. Regionovedenie. Mezhdunarodnye otnosheniya [Science Journal of Volgograd State University. History. Area Studies. International Relations], 2020, vol. 25, no. 2, pp. 233-240. DOI: https://doi.org/ 10.15688/jvolsu4.2020.2.17
\end{abstract}

УДК 327(575.1+479.24)“19/20”

Дата поступления статьи: 12.11.2019

ББК $66.4(4 / 8)$ Дата принятия статьи: 16.03 .2020

\section{ОБЗОР УЗБЕКСКО-АЗЕРБАЙДЖАНСКОГО НАУЧНО-ИССЛЕДОВАТЕЛЬСКОГО СОТРУДНИЧЕСТВА В ГОДЫ НЕЗАВИСИМОГО РАЗВИТИЯ}

\author{
Азер Надир огли Адыгезалов \\ Андижанский государственный университет, г. Андижан, Узбекистан
}

Аннотация. Введение. В статье приводятся сведения о становлении узбекско-азербайджанского научного сотрудничества в годы независимого развития двух стран. Статья описывает солидную договорную базу в научной области, в числе которой Соглашения между Министерствами народного образования, Академиями наук, высшими учебными заведениями двух стран, а также сотрудничество в области аттестации научных и научно-педагогических кадров высшей квалификации. Методы и материальл. В статье приводятся также данные о непосредственном сотрудничестве двух стран в области естественных, точных и гуманитарных дисциплин, способствующих тесному и плодотворному взаимодействию научных кругов двух стран, 
охватывающих все грани партнерских связей данной сферы. Анализ. В статье анализируется процесс многогранного научного сотрудничества Узбекистана и Азербайджана, которое происходит путем установления тесных контактов между учеными и научно-исследовательскими центрами двух стран, осуществлением совместных исследований по актуальным проблемам, взаимных стажировок и научных командировок, а также участием в международных научных конференциях и симпозиумах. Тесные взаимные контакты осуществляются также в форме обмена научными кадрами и трудами. Результаты. Многогранное узбекско-азербайджанское научное сотрудничество, рассмотренное в статье, характеризуется следующими признаками: двусторонними соглашениями и договоренностями в научной сфере; непосредственными разработками в области естественных, точных и гуманитарных наук; осуществлением взаимных стажировок и научных командировок; обменом научными кадрами и трудами.

Ключевые слова: узбекско-азербайджанское взаимодействие, научное сотрудничество, Министерство народного образования, Академия наук, высшее учебное заведение.

Цитирование. Адыгезалов А. Н. огли. Обзор узбекско-азербайджанского научно-исследовательского сотрудничества в годы независимого развития // Вестник Волгоградского государственного университета. Серия 4, История. Регионоведение. Международные отношения. -2020. - Т. 25, № 2. - С. 233-240. - (На англ. яз.). DOI: https://doi.org/10.15688/jvolsu4.2020.2.17

Introduction. As is well known, the significant role in the co-operation pertaining to humanities is given to the scientific sphere, as the level of a country's progress and socio-economic situation of society depends on the state of its development. The process of collaboration between Uzbekistan and Azerbaijan in this field is traced back brightly enough. Thus, one of the first agreements between the countries was the Agreement between the Ministry of Public Education of the Republic of Uzbekistan and the Ministry of Public Education of the Republic of Azerbaijan, which came into force on March 2, 1992 and was concluded within five years [2, 1. 68].

The further improvement of the bilateral relations in the given sphere was held within the framework of the agreement between the Government of the Republic of Uzbekistan and the Government of the Republic of Azerbaijan on the co-operation in the scientific, technical and informational field concluded on May 27, 1996 $[1,1.82]$. Thus, according to this agreement, the State Committee of Science and Technique of the Republic of Uzbekistan, the Academy of Sciences of the Republic of Uzbekistan, and the State Committee of Science and Technique of the Republic of Azerbaijan, the Academy of Sciences of the Republic of Azerbaijan activate their contacts [10, 1. 216].

The agreement between the Government of the Republic of Uzbekistan and the Government of the Republic of Azerbaijan on the co-operation in the field of training highly-qualified scientific and scientific-pedagogical personnel promoted further developing of scientific relations [2, 1. 70].
The development of the further contact in this field was fulfilled within the framework of paragraph II of the Program of collaboration in the sphere of science, culture, and art between the Republic of Uzbekistan and the Republic of Azerbaijan for the period of 1998-2000. Afterwards, scientific contacts were realized within the framework of the Program of economic co-operation between the Republic of Uzbekistan and the Republic of Azerbaijan for the period of 2001-2010 when the scientists of the two countries held bilateral scientific elaborations.

Interrelations between the Academies of Sciences of the two countries. The fruitful scientific co-operation between the two states, first of all, was observed in the sphere of exact and natural sciences. Thus, during the period of 2001-2005 the implementation of the co-project in the sphere of oil and gas through the branch of international INTAS (The International Association for the Promotion of Cooperation with Scientists from the New Independent States of the Former Soviet Union) grant was planned. Together with Azerbaijani scientists tenders on the co-project, which was directed to the enhancement of biomass gasification's technological process and to raising the effectiveness of oil mining by means of using scientific-technical exploitation of the thermophysics department's scientists of the Academy of Sciences of the Republic of Uzbekistan, were worked out. It is expected to enhance the scientific base of the new emulsive type of technology of working agents preparation in oil mining, and to reveal the correlation of the 
parameters of gasification processes, as well as to implement them in recycling the refuse of cotton. The tenders were observed by the representatives of "Uzbekneftegaz" and were directed to the Institute of Petro-Chemistry Processes of the National Academy of Azerbaijan $[2,1.14]$.

Institute of seismology of the AS of Uzbekistan and the Centre of Seismological Service of Azerbaijan concluded a treaty on the scientific-technical collaboration on June 6, 2001. In accordance with the treaty, the sides exchange quarterly seismological bulletins and catalogues, as well as according to their mutual agreement they give information on the problem of forecasting earthquakes $[8,1.66]$.

In 2010, some work on the geologicalgeophysical data exchange was conducted. The participation of Uzbek and Azerbaijani leading specialists in the projects on the study of geodynamics and modern tectonic waves, spreading in the earth's crust and disconnecting to continental breaks to the south of Central Asia and Azerbaijan, was planned [7, 1. 70].

Permanent partnership relations were arranged on the equivalent mutual exchange between the patent departments of the two countries: patent literature and state funds of scientific-technical information, scientific-technical literature.

Uzbek Research Institute of Selection and Cotton Seed-Growing and Uzbek Research Institute of Uzbekistan's Cotton-Growing, on the one hand, and Azerbaijani Cotton-Growing Research Institute, on the other hand, are actively taking part in conducting co-research on selection of resistant sorts of cotton and wheat, responding the agro-climatic conditions of the both countries in the same way, working out effective methods of hybridization of grain-spike and grain legumes, the mutual experience exchange is held on gardening, wine-growing and wine-making. Besides, annual scientific missions to Azerbaijan and Uzbekistan are organized in order to exchange scientific literature and implement co-publications on current matters of selection, genetics, and seed-growing.

The Centre on Science and Technologies directed its tenders on the development of scientific-technical co-operation with Azerbaijan in the agricultural sphere for generalization to the
Ministry of Agriculture and Water-Supply of the Republic of Uzbekistan. In these tenders the most significant trends of scientific-technical collaboration were given concrete expression, the mechanism of implementing co-projects in stipulations of share financing was offered, and the perspectives of enhancing co-operation via co-participation of the two states' scholars in the programs and contests of international funds and projects of scientific-technical organizations, were pointed out $[2,1.15]$.

Moreover, together with Azerbaijani scholars astronomic observations and radio-astronomic research work were held, they negotiated on concluding a direct treaty in the mathematicalcybernetic field with the Institute of cybernetics of the Azerbaijan Academy of Sciences. Besides, a project of measures in the sphere of using solar and other non-traditional energy sources was worked out [2, 1. 15-16].

The scientists of Samarkand department of the Uzbekistan Academy of Sciences worked out and directed for observation to Azerbaijani State oil academy a project on the issue "Hydro-dynamic bases of deep deposits' exploitation" [2, 1. 16].

Botanical gardens of the Uzbekistan Academy of Sciences implemented an active exchange of scientific experience with the Central Botanical gardens of the Azerbaijan National Academy of Sciences. With the help of scientific missions of research fellows of Botanical gardens of the Uzbekistan Academy of Sciences, Botanical gardens of Baku and Mardakans organized various scientific expeditions. Dr. Rusanov N.F., Candidate of Biological Sciences Abdurahmonov A.A., Arifhonov K.P., Shtonda N.I., Korchagina A.M were the visitors to the Central Botanical gardens from the Uzbekistan Academy of Sciences. Nowadays, Botanical gardens of the Uzbekistan Academy of Sciences support the seed index exchange with the Central Botanical gardens of the Azerbaijan National Academy of Sciences, the head of which is Doctor of Biological Sciences Orudj Veli ogli Ibodli.

Head of the glycoside chemical laboratory of Institute of Chemistry of botanical substances (IChBS) of the Uzbekistan Academy of Sciences M.I. Isayev conducts co-operation with the coworkers of Botanical Institute of the Azerbaijan National Academy of Sciences and Azerbaijan State medical University. 
Beginning from 2005, the National Academy of Aviation of Azerbaijan represented by the rector Pashayev A.M., who acted according to the regulations, and Physically-technical Institute of the Uzbekistan Academy of Sciences represented by general director Lutpullayev S.L., who acted in accordance with the regulations of the institute, concluded an agreement on cooperation and creative collaboration in the sphere of studying innovative technologies and new generation devices on the issue: "Creating and studying optically-electrical characteristics of the new generation of devices on the basis of gallium arsenide (GaAs)" [8, 1. 65].

Besides, co-operators of Physicallytechnical Institute of the Uzbekistan Academy of Sciences take mutual part with Azerbaijani scholars in working out the project "Working out the production technologies of semi-conducting photo-electronic converters with selective photosensitivity" [8, 1. 65-66].

Especially close cooperation was in the informational and electronic field, as until 2008 a number of international conferences both in Tashkent and in Baku had been held. These discussions were reflected in dozens of publications: "Photo-electrical effects in microregime structures", "Optical damping of photoflow in three-barrier photo-diode", "Micro-regime photo-detectors", "Hetero-layers with wide-zone opening - filter on texture surfaces", "Amplifiers of optical signals on the basis of bio-polar phototransistor hetero-structures", "Silicic photoreceivers of short-wave diapason for distant control systems", "Engineering-field effects in a bilaterally-sensitive arsenide-gallium photo-diode hetero-structure", "The analysis of electronic processes in iso-type $m_{1}$-nGaAs- $\mathrm{nAl}_{0,08} \mathrm{Ga}_{0,82}$ $\mathrm{In}_{0,1}$ As- $\mathrm{m}_{2}$ - hetero-structure", "Photo-electrical features of photo-detector $\mathrm{m}_{1}-\mathrm{nGaAs}^{-\mathrm{nAl}_{0,08}}$ $\mathrm{Ga}_{0,82} \operatorname{In}_{0,1}$ As- $\mathrm{m}_{2}$ - structures", "The amplifier of alternating signals on field-effect transistor", "Optical relay with distant control", "The study of photo-electrical features of photo-galvanic affluent photo-receivers", "Engineering heterotransitions for photo-receivers on the basis of GaAs-AlGaInAs" [8, 1. 65-66].

The same contacts were established between scholars and scientific centers of the two countries in the sphere of Humanities. Thus, coworkers of Archaeological Institute of the
Uzbekistan Academy of Sciences established scientific contacts with their Azerbaijani colleagues, participating in conferences, scientific publications, big projects, as well as in defenses of dissertations both in Azerbaijan and in Uzbekistan.

Archaeological Institute of the Uzbekistan Academy of Sciences supports the continuation and further improvement of scientific relations between Uzbek and Azerbaijani specialists in the cultural field, especial intensity of which took place in the epoch of the Early and Late Middle Ages.

Direct interrelations between higher education institutions. An important role in setting direct scientific interconnections is given to treaties, agreements and memoranda between higher education institutions of the two countries, which stipulate for the exchange of scientific data and scientific-technological literature between the high schools in agreement, holding seminars and symposiums, organization of scientific meetings, experience and information exchange connected to the educational process, carrying out various events, exhibitions and festivals. Thus, on March 28, 2011, the delegation of Azerbaijani Diplomatic Academy arrived in Tashkent in order to establish close communication with the professorial teaching and pedagogical staff of University of the World Economy and Diplomacy.

On December 18, 2013, an agreement on setting mutually beneficial relations between Tashkent State Pedagogical University named after Nizami and Baku State Pedagogical University was signed. This document is to create and broaden the relations between the two universities to deepen scientific connections. The memorandum takes into account the exchange of scientific data and scientific technical literature between these institutions, holding seminars and symposiums as well as organizing conferences, exchanging experiences and information related to the educational process, holding various events. The document contains a point about the issues of scientific articles and materials about these higher education institutions in the scientific journals of ASPU and TSPI [5, 1. 67].

On April 25, 2014, the Memorandum of collaboration between the Academy of Arts of Azerbaijan and Institute of Arts and Design of Uzbekistan named after Kamoliddin Behzod was signed. In the Memorandum they highlight the 
development of bilateral cooperation, experiences exchange between the institutions, holding exhibitions and festivals, mutual exchange in enhancing genres of painting art, organization of two-side tours and events, exhibitions of eminent artists of the both countries and a number of other issues.

On October 20, 2015, Ganja and Tashkent state universities signed documents on cooperation. The heads of the universities signed the Memorandum of friendship and collaboration in Ganja. It runs about the forthcoming student and lecturer exchange, scientific research being conducted concertedly, holding conferences and preparing books for edition, etc.

The significant part in setting direct scientific relations is given to the agreements between the higher education institutions of the two countries.

So, in order to discuss the opportunities of the scientific co-operation and to create co-work in the field of science, the delegation of Azerbaijani State Economical University (ASEU) made a visit to Uzbekistan and Kyrgyzstan. During the visit an agreement between Institute of Economy of the Uzbekistan Academy of Sciences and Scientific Research Institute of Economic Searches of ASEU was signed.

Tashkent State Agrarian University closely collaborates with the higher education institutions and scientific research institutes of the CIS countries which concluded over 18 agreements, particularly, one of them was concluded with Azerbaijan.

In July, 2019, a memorandum on mutual understanding in the sphere of education and science between International University of tourism "Silk Road" in Samarkand and Azerbaijan University of tourism and management was signed. The document stipulates for measures on experience and knowledge, implementing exchange programs for specialists in the touristic field, as well as organizing seminars, conferences and other coordinated projects.

On November 20, 2019, Azerbaijan State University of oil and industry (ASUOI) and Tashkent State Technical University (TSTU) signed a memorandum. The agreement points out the development of mutually beneficial cooperation, experience and knowledge exchange between the higher education institutions, as well as the organization of other mutually beneficial concerted projects.
The role of conferences, symposiums and other events in the development of scientific contacts. Beginning from the first years of their state independence, Uzbekistan and Azerbaijan hold international conferences. Thus, in 1992, Baku hosted representatives of Uzbekistan on the International conference "Architecture and art of Near East and Middle East". M. Bulatov, A. Madraimov, R. Taktash, P. Zakhidov, Sh. Asqarov, K. Kryukov, A. Mahkamov, H. Tursunov arrived from Tashkent to Baku. The most interesting was the report of one of the main figures in Uzbek science, M. Bulatov "The matters of Muslim Renaissance" [9, p. 37].

In October 2009, a practical seminar on the topic "The sources on the history of the Temurids: descriptions, translations, research papers" took place in the State Museum of the Temurids. The leading and young scholars of research institutions and higher education institutions of Uzbekistan, as well as specialists from Azerbaijan and Russia took part in it.

The creation of the State Museum of the Temurids promotes deeper investigation of significant stages of our history, deep study of archaeological excavations and further knowledge enrichment about Sakhibkiran.

The staff of the State Museum of the Temurids together with scientists of research institutions and higher education institutions of Uzbekistan organize traditional practical seminars in order to study the history of Amir Temur and the Temurids, popularizing researches held in our country and abroad on these subjects [3].

On March 26, 2013, with the support of chairmanship of DVV international in South Caucasus and Turkey, Azerbaijani scholars (Babek Mamedov, Nizami Geydarov, Esmira Musayeva) made visit to Institute of History of the Uzbekistan Academy of Sciences. The aim of the visit was the acquaintance with the work experience of Oral history, created in 2010 within the framework of the project of DVV filial branch in Uzbekistan and acting under the leadership of Institute of History.

Over 30 people representing such organizations as Institute of History of the Uzbekistan Academy of Sciences, Coordination resource center on the matters of recent history under the leadership of The Ministry of Higher 
education institutions of the Republic of Uzbekistan, the Museum of Victims of Political Repression under the leadership of the Uzbekistan Academy of Sciences, Uzbek State university of World Languages, National University of Uzbekistan, Kara Kalpak State University, National company "Uzbektourism", and the Institute of Orientalism of the Uzbekistan Academy of Sciences, participated in the seminar. Overall, the seminar was held on a high scientifically-theoretical level, there were worked out practical recommendations for forming and developing the center of oral history in Azerbaijan.

On February 25, 2014, a seminar on the issue "The place of Amir Temur in the history of the world" (on the basis of Uzbek and Azerbaijani people's friendship) took place in Tashkent State Pedagogical University named after Nizami with the support of the Friendship Community "Uzbekistan-Azerbaijan" and Azerbaijani cultural center named after Geydar Aliyev.

The conference was opened by the chairman of the Friendship Community "Uzbekistan-Azerbaijan" Sharipov Sh.S. and Ambassador extraordinary and plenipotentiary of the Republic of Azerbaijan Guseyn Guliyev.

After that Azerbaijani and Uzbek scholars and specialists invited to the conference made their reports on various topics. Among them there were deputy of Milli Medjlis of Azerbaijan Djafarov N. with his speech on the issue "The image of Amir Temur in Azerbaijani literature"; Azerbaijani writer Yunus Oguz, the author of the book "Amir Temur", with his report "Amir Temur as the world's ruler in the research works of Yunus Oguz"; Professor of Institute of Orientalism of the Uzbekistan Academy of Sciences named after Beruni Yusupova D. "The study of the history of Amir Temur and the Temurids in Uzbekistan"; senior lecturer Rahmatullayeva O. - "The creative works of Amir Temur in Azerbaijan"; editor-in-chief of the "Darakchi" newspaper Djabbarov R. "Amir Temur and literature" [6, 1. 47].

The co-operation of scientists of the two countries in the sphere of music and art also deserves attention. Thus, in March, 2009, in Baku a scientific symposium "The world of mugam"was held, among the participants of which there was eminent explorer of Uzbek traditional music R. Yunusov [9, p. 37].
In December of the same year, Institute of Architecture and Art of Azerbaijan organized the International seminar "Informational culture of Eurasia", on which Dr. of the History of Art K. Akilova made her speech on the topic "Modern art of Uzbekistan in the aspect of informational culture's problems" [9, p. 37].

On October 25, 2011, there was a conference in Tashkent, aimed at reflecting the whole variety of cultural relations between Azerbaijani and Uzbek people, timed for the $870^{\text {th }}$ anniversary of Nizami's date of birth (1141-1209), and symbolically coincided with the prominent Azerbaijani singer and composer Muslim Magamayev's day of memory (1942-2008).

The organizers of the event were the Academy of Arts of Uzbekistan and Institute of Architecture and Art of the Academy of Sciences of Azerbaijan with the promotion of the Embassy of the Republic of Azerbaijan in Uzbekistan.

On the conference reports of scholars of the Institute of Architecture and Art of Azerbaijan were represented. The science of Uzbekistan was represented by the scholars of National Institute of Arts and Design named after Kamoliddin Behzod, Institute of the History of Arts, specialists of State Conservatoire, the Gallery of Fine Arts, Institute of Orientalism and Institute of History.

In conclusion of the event Uzbek and Azerbaijani dances were performed by the students of Tashkent Choreography College. The performance was created by Artist Emeritus of Uzbekistan Erkin Kahharov and Professor of York University in Canada Sashar Zarifa.

On January 11, 2014, the ceremony of signing the Memorandum of co-operation between scientific medical libraries of Azerbaijan and Uzbekistan took place in Baku in Azerbaijani Cultural Center named after Geydar Aiyev with the support of Azerbaijani Embassy in Uzbekistan. The Memorandum stipulates the experience exchange on actual issues in the sphere of libraries and information, the automation of the processes in the sphere, as well as holding conferences, seminars, courses, on-line discussions and events in this field, exchanging books, journals, electronic issues between the libraries, organizing exhibitions and creating rooms exposing achievements of both countries in medical sphere.

A special place in the scientific collaboration is taken by so-called "personnel exchange" of the 
two republics. On October 22-29, 2012, the delegation of the Friendship Community "Uzbekistan-Azerbaijan" consisting of four members visited Azerbaijan on scientific and cultural purpose. Within the framework of the visit, first they attended the international practical seminar devoted to the $130^{\text {th }}$ anniversary of Guseyn Djavid's date of birth. Then there was a meeting organized by the executive director and members of the Friendship Community "Uzbekistan-Azerbaijan". On the meeting, they discussed the matters of regular co-operation of the two communities and of holding various events both in Uzbekistan and in Azerbaijan [4, 1. 38].

During the last years on the project of the Azerbaijani Cultural Center, a trip to Uzbekistan of deputy of Milli Medjlis of Azerbaijan, correspondent member of the Azerbaijan Academy of Sciences, academician Nizami Djafarov, scientist-writer, author of the book "Amir Temur" Yunus Oguz, researchers of the National Academy of Sciences of Azerbaijan Almaz Ulvi Binnatova, Halida Halid, director of the State Gallery of Arts of Azerbaijan Elnur Guseynov, provost of the State Academy of Arts of Azerbaijan Salhab Mamedov, director of the State Museum of Arts of Azerbaijan Chingiz Farzaliyev was organized. They held rational meetings and experience exchange with their colleagues from Uzbekistan.

To sum up, having analyzed all the above mentioned, we can conclude that quite close cooperation in the scientific sphere had been set between the fraternal republics Azerbaijan and Uzbekistan over the course of history. This cooperation was going firmer and more developed, becoming stronger and stronger year by year. After having obtained the independence, the points of contact in this sphere are taking new turns and gaining agreements, promoting the further improvement of scientific collaboration between the republics. This cooperation is manifested in the fruitful development and expansion of bilateral ties in the field of natural, exact and humanitarian sciences between the Academies of Sciences, research institutes, and higher education institutions of the two countries. The establishment of direct scientific contacts is also facilitated by the implementation of joint research on current scientific problems, mutual internships, participation in international scientific conferences and symposia, as well as the exchange of scientific personnel, mutual trips of scientists to give lectures and consultations. The listed forms of cooperation create favorable conditions for closer and deeper mutual familiarization with scientific achievements, thereby contributing to the further development of scientific contacts between the two countries.

Results. As it can be seen, the scale of the Uzbek-Azerbaijani scientific cooperation is so wide that there is practically no sphere in which mutual cooperation between the two countries is not reflected, where scientists and research centers do not conduct joint research in the field of pressing bilateral problems and tasks.

On the basis of archival documents, the article provides data revealing the process of bilateral scientific cooperation, based on the following factors:

- bilateral agreements and arrangements in the scientific field;

- direct development in the field of natural, exact sciences and humanities;

- implementation of mutual internships and scientific missions;

- exchange of scientific personnel and labor.

\section{REFERENCES}

1. Dokumenty o kulturnom sotrudnichestve gosudarstv-uchastnikov SNG (polozheniya, soglasheniya, protokoly) [Documents on Cultural Cooperation of the CIS Member States (Regulations, Agreements, Protocols)]. Tsentralnyy gosudarstvennyy arkhiv Respubliki Uzbekistan (CGA RUz) [Central State Archive of the Republic of Uzbekistan], F. M-7, Op. 1, Ed. khr. 333. 1171.

2. Mezhpravitelstvennye soglasheniya o sotrudnichestve mezhdu Respublikoy Uzbekistan i stranami SNG. Azerbaydzhan. T. 1 [Intergovernmental Agreements on the Cooperation Between the Republic of Uzbekistan and the CIS Countries]. Tsentralnyy gosudarstvennyy arkhiv Respubliki Uzbekistan (CGA RUz) [Central State Archive of the Republic of Uzbekistan], F. M-7, Op. 1, Ed. khr. 722.1341.

3. Narodnoe slovo [People's Word]. 2009. October 22.

4. Otchet Obshchestva druzhby «UzbekistanAzerbaydzhan» za 2012 god [Report of the Friendship Community "Uzbekistan-Azerbaijan" for 2012]. Obshchestvo druzhby "Uzbekistan-Azerbaydzhan» [Friendship Community “Uzbekistan-Azerbaijan”]. 761. 
5. Otchet Obshchestva druzhby «UzbekistanAzerbaydzhan» za 2013 god [Report of the Friendship Community "Uzbekistan-Azerbaijan" for 2013]. Obshchestvo druzhby "Uzbekistan-Azerbaydzhan» [Friendship Community “Uzbekistan-Azerbaijan"]. 821.

6. Otchet Obshchestva druzhby «UzbekistanAzerbaydzhan» za 2014 god [Report of the Friendship Community "Uzbekistan-Azerbaijan" for 2014]. Obshchestvo druzhby "Uzbekistan-Azerbaydzhan» [Friendship Community "Uzbekistan-Azerbaijan"]. 881.

7. Papka - Vizit Prezidenta Azerbaydzhanskoy Respubliki I.G. Alieva v Uzbekistan. 27-28 sentyabrya 2010 g. [File - Visit of President of the Republic of Azerbaijan I.G. Aliyev to Uzbekistan. September 27-28, 2010]. Tekushchiy arkhiv Upravleniya po sotrudnichestvu so stranami SNG (TA US SNG) i Rossii. Azerbaydzhan. Ministerstvo inostrannykh del Respubliki Uzbekistan [Current Archive of the Administration of Collaboration Between CIS Countries (CA AC the CIS) and Russia. Azerbaijan. Ministry of Foreign Affairs of the Republic of Uzbekistan]. 981.

8. Papka-Vizit Prezidenta Respubliki Uzbekistan I.A. Karimova vAzerbaydzhan. 11-12 sentyabrya 2008 g. [File - Visit of President of the Republic of Uzbekistan
I.A. Karimov to Azerabijan. September 11-12, 2008]. Tekushchiy arkhiv Upravleniya po sotrudnichestvu so stranami SNG (TA US SNG) i Rossii. Azerbaydzhan. Ministerstvo inostrannykh del Respubliki Uzbekistan [Current Archive of the Administration of Collaboration Between CIS Countries (CAAC the CIS) and Russia. Azerbaijan. Ministry of Foreign Affairs of the Republic of Uzbekistan]. 1121.

9. Salamzade E. Vzaimosvyazi iskusstvoznaniya Uzbekistana i Azerbaydzhana [The Interrelations of the History of Art of Uzbekistan and Azerbaijan]. Sanyat-Art-Iskusstvo, 2010, no.1, pp. 36-37.

10. Soglasheniya, dogovora o kulturnom sotrudnichestve mezhdu ministerstvom po delam kultury Respubliki Uzbekistan i ministerstvami kultury stran SNG i zarubezhnykh stran na 1995-2000 gg. T. 1 [Agreements, Treaties on the Cultural Cooperation Between the Ministry of Cultural Affairs of the Republic of Uzbekistan and the Ministries of Culture of CIS Countries and Foreign Countries During 19952000. Vol. 1]. Tsentralnyy gosudarstvennyy arkhiv Respubliki Uzbekistan (TsGA RUz) [Central State Archive of the Republic of Uzbekistan], F. M-7, Op. 1, Ed. khr. 330. 2461.

\section{Information About the Author}

Azer Nadir ogli Adygezalov, Senior Lecturer, Department of History of Uzbekistan, Andizhan State University, Universitetskaya St., 129, 170100 Andizhan, Uzbekistan, azerbay23@mail.ru, https://orcid.org/0000-0002-1985-4976

\section{Информация об авторе}

Азер Надир огли Адыгезалов, старший преподаватель кафедры истории Узбекистана, Андижанский государственный университет, ул. Университетская, 129, 170100 г. Андижан, Узбекистан, azerbay23@mail.ru, https://orcid.org/0000-0002-1985-4976 